\title{
Morphological identification and DNA barcoding used for diet analysis of gilthead seabream (Sparus aurata) in its expanding northerly range
}

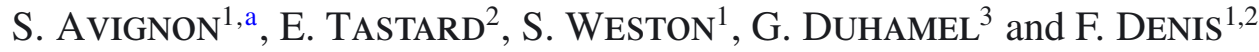 \\ ${ }^{1}$ UMR Biologie des Organismes et Ecosystèmes Aquatiques (BOREA, UMR 7208), MNHN/Sorbonne \\ Universités/UMPC/UCBN/CNRS/IRD/UA, Museum National d'Histoire Naturelle, Station de Biologie Marine de Concarneau, \\ Place de la Croix, 29900 Concarneau, France \\ 2 PRES LUNAM Université du Maine, Laboratoire Mer, Molécules, Santé (EA 2160), Institut Universitaire Mer et Littoral FR3473 CNRS, \\ Avenue Olivier Messiaen, 72085 Le Mans cedex 9, France \\ 3 UMR Biologie des Organismes et Ecosystèmes Aquatiques (BOREA, UMR 7208), MNHN/Sorbonne \\ Universités/UMPC/UCBN/CNRS/IRD/UA, Museum National d'Histoire Naturelle, 57 rue Cuvier, 75005 Paris, France
}

Received 30 August 2016; Accepted 28 November 2016

\begin{abstract}
The gilthead seabream, Sparus aurata, is common in the Mediterranean Sea and along the Atlantic coasts of Portugal, Spain and France. Abundance of $S$. aurata has recently increased along the Brittany coast, showing good adaptation and acclimatisation to northern waters away from its original distribution range. The physiological adaptations (diet, reproduction, growth) of this fish to colder water could even lead to its colonisation of the English Channel. The ability to eat and digest hard prey makes this fish an important consumer of bivalves. The aim of this study was to make a preliminary evaluation of the diet of the gilthead seabream in its northern range of distribution. Prey items from stomach contents of wild adults from various sites along the East Atlantic coast of France to the English Channel were identified morphologically when it was possible, e.g. in presence of decapod appendices, shells of bivalves, or using DNA barcoding. Diet composition was analysed against sites, fish length and month of sampling using the frequency of occurrence $(\% \mathrm{~F})$ and weight relative proportion $(\% \mathrm{~W})$. Results showed that the diet of $S$. aurata was mainly composed of bivalves, malacostracans and gastropods with a huge dominance of Mytilus sp. $(\% \mathrm{~F}=51.5$ and $\% \mathrm{~W}=40.2)$. This first diet analysis of individuals from the northern range of the species distribution showed its ability, as an opportunistic feeder, to find prey in newly colonised ecosystems and its preference for some organisms, especially mussels.
\end{abstract}

Keywords: Diet / DNA identification / distribution range / North-eastern Atlantic / Sparus aurata

\section{Introduction}

Global warming may be the main cause of modification in structure, biodiversity and functioning of ecosystems (Parmesan and Yohe 2003). This impact on marine environments has become prominent and alterations are increasingly observed, such as species extinction, community shift or geographical distribution changes (Carlton 1993; Occhipinti-Ambrogi 2007; Lenoir et al. 2011). It is expected that warming waters will lead to a northward shift in the mean latitude of thermal specialists in the North, notably in the north-eastern Atlantic, and a southward shift of species in the southern hemisphere (Dulvy et al. 2008). Recently, Montero-Serra et al. (2015) analysed the changes in distribution and occurrence rate of six common species of fish in the north-eastern Atlantic Ocean. They showed a strong relationship between their northern move-

\footnotetext{
a Corresponding author: savignon@mnhn.fr
}

ment and the increase of sea temperature, showing the impact of global warming on fish community changes. For example, the decline in abundance of Atlantic cod Gadus morhua in the North Sea could be due to northward movements in connection with increased temperatures (Rindorf and Lewy 2006). Moreover, the impact of climate change on cod stocks is notably due to its influence on plankton; warming causes a decrease in the quality and quantity of plankton food available for cod larvae at the southern edge of the distribution area (Beaugrand and Kirby 2010).

The understanding of adaptive processes of a species at the edge of its distribution is essential in ecology studies and especially for fishery management. The gilthead seabream Sparus aurata (Linnaeus, 1758), a euryhaline and eurythermal sparid, is typically found along the Mediterranean Sea and French East-Atlantic coasts, where it is known to perform trophic migrations between coastal lagoons and the sea (Tancioni et al. 2003; Mariani 2006; Mercier et al. 2012). In north-eastern 
Table 1. Percentage of frequency of occurrence $(\% \mathrm{~F})$ for main prey of Sparus aurata in the southern part of the distribution area.

\begin{tabular}{cccc}
\hline Area & Main prey & $\% \mathrm{~F}$ & References \\
\hline & Bivalves & 8.7 to 40.9 & \\
Central west coast & Carcinus aestuarii & 21.7 to 27.3 & Tancioni et al. (2003) \\
of Italy & Amphipods & 18.2 to 34.8 & \\
& Polychaetes & 19.6 & \\
\hline Tunisian coast & Arthropods & 49.1 & \multirow{2}{*}{ Hadj Taied et al. (2013) } \\
(Gulf of Gabes) & Molluscs & 38.5 & \\
\hline \multirow{2}{*}{ Northeastern Algeria } & Fish & 59.4 & \multirow{2}{*}{ Chaoui et al. (2005) } \\
(Mellah lagoon) & Bivalves & 35.5 & \\
\hline Southern Portugal & Thallophytes & 36.9 & \multirow{2}{*}{ Pita et al. (2002) } \\
(Ria Formosa lagoon) & Gastropods & 100 & \\
\hline
\end{tabular}

Atlantic waters, this species is still considered rare but a significant increase of wild gilthead seabream populations has been observed in coastal zones in the northern boundary of its distribution area, a phenomenon which can be linked to climate change (Coscia et al. 2011). For a few years, specimens of $S$. aurata have been caught in Irish waters (Fahy et al. 2005; Craig et al. 2008; Quigley 2015). Furthermore, a few specimens were caught along the coast of Denmark in 2014 (Pers. comm.). Along the coast of Brittany, the gilthead seabream landing increased from 11 to 146 tons between 2002 and 2014 and fishing development has also been observed along the French coast of the English Channel with no significant landing before 2005 and 15 tons fished in 2014 (sources: FAO, 2015 and personal communication from fish auction staff) through surveys with fish auctions. The increased number of gilthead seabream being sold in fish auctions in the North of France also suggests the settlement of the species in the eastern part of the English Channel and the possibility of self-sustaining populations in the colder water limit.

The increase in abundance of non-native species into a coastal area can impact the functioning of an ecosystem, especially through the modification of the food web equilibrium. For example, the establishment of a new species can lead to imbalanced predator and prey populations (Parmesan and Yohe 2003; Edwards and Richardson 2004). In fact, this can affect the native fauna, since some species may become potential prey. In addition, predation can have an effect on the local maritime economy, such as shellfish losses due to predation by the gilthead seabream. Predation has already been reported in aquaculture concessions along the Mediterranean coast, especially in the Adriatic Sea where the concentration and abundance of seabream populations around mussel farms has caused considerable losses, indicating a strong negative impact on farm stability (Šegvić-Bubić et al. 2011; Glamuzina et al. 2014). While the economic impact is evident in this area, it has not yet been evaluated along the coast of Brittany despite significant losses on shellfish farmed in recent years. The predation of $20 \%$ of mussels farmed in the Bay of Brest (Brittany, France), leading to $e 500000$ of losses during the summer of 2014 (Anonymous 2014), was presumed to be due to a higher abundance of the gilthead seabream along the Brittany coast.

Previous diet studies concerning the gilthead seabream have focused on the Mediterranean Sea, in the southern part of its distribution area (Table 1). In these studies, diet com- position was determined by a visual identification of prey from stomach contents, requiring an exhaustive knowledge of prey morphological diversity. Due to the mastication and the degradation of prey during digestion, it is almost impossible to achieve full identification. A proportion of prey remains unidentified, often not even being identified into higher taxonomic groups. Other tools have been developed to assist in morphological identification, such as stable isotope analysis which provides information about dietary shifts and trophic interactions in food webs (Espinoza et al. 2015). However, DNA analysis of consumed prey can provide a higher taxonomic level of diet identification and is used more and more (Deagle et al. 2005; Corse et al. 2010). A part of the mitochondrial DNA cytochrome $c$ oxidase I (COI) gene, barcode region, is widely used for species identification because of its level of variability (Avise et al. 1987), and is becoming an effective marker for dietary DNA analysis (Paquin et al. 2014). The mitochondrial $16 \mathrm{~S}$ region can also be used for species level discrimination (Gorokhova 2006; Taguchi et al. 2014). Universal primers have been developed for amplification of COI and $16 \mathrm{~S}$ fragments from a high range of taxonomic levels (Folmer et al. 1994; Palumbi 1996). However, degradation of prey DNA inside stomachs prevents long fragment PCR amplification (Symondson 2002). To overcome this issue, mini-barcodes can be used and it has been shown that short fragments from $200 \mathrm{bp}$ can lead to significant identification (Meusnier et al. 2008). Nevertheless, the use of universal primers in studies of animal diet often does not allow any PCR amplification since prey DNA is degraded (Jarman et al. 2004).

In the present study, we investigated the diet of $S$. aurata in the northern boundary of its distribution area in order to understand the impact on native fauna and shellfish farms, especially in targeting mussel and oyster prey. An approach with molecular markers was carried out with PCR-based techniques for diet determination. As universal primers were not appropriate for any prey identification, this approach was based on the combined used of universal and specific primers for given groups known to be prey of $S$. aurata. These specific primers from the COI and $16 \mathrm{~S}$ regions were developed for the study and were used in order to thoroughly identify prey diversity inside stomach contents of wild fish. Moreover, an assay of controlled predation was carried out on farmed fish in order to evaluate the effectiveness of universal and specific primers in amplifying prey DNA at different times after ingestion. This study 


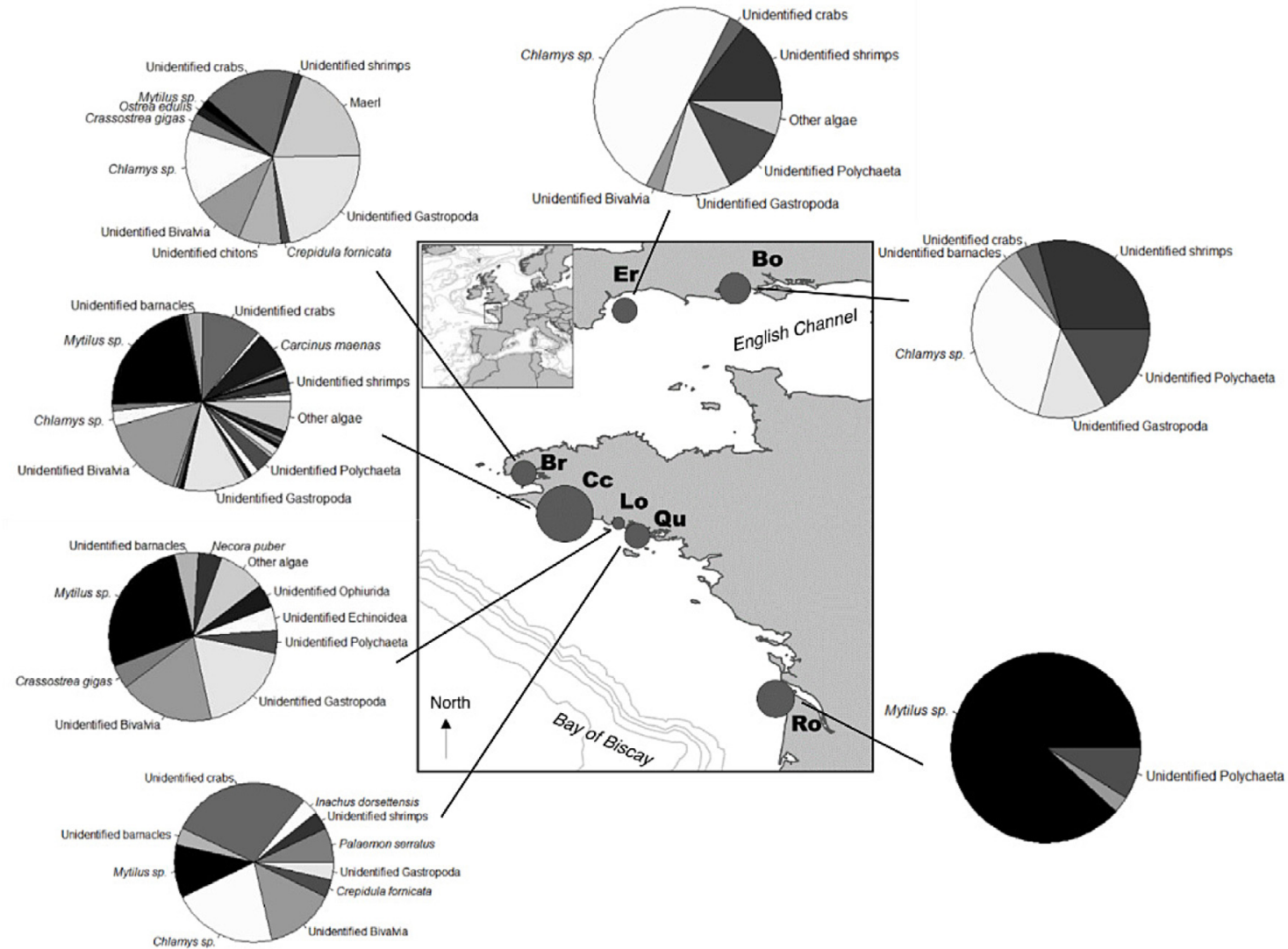

Fig. 1. Sampling site. Circle size is proportional to the number of individuals sampled per site: Bay of Bournemouth (Bo, $N=9$ ), Bay of Torquay (Er, $\mathrm{N}=18)$, Brest $(\mathrm{Br}, \mathrm{N}=15)$, Concarneau (Cc, $\mathrm{N}=52)$, Lorient (Lo, $\mathrm{N}=6)$, Quiberon $(\mathrm{Qu}, \mathrm{N}=12)$ and $\mathrm{Royan}(\mathrm{Ro}, \mathrm{N}=30)$. Pie charts show the percentage of frequency of prey occurrence $(\% \mathrm{~F})$ per sites at the lower taxonomic level. Labels of species indicate whether $\% \mathrm{~F}>5$.

provides the first data on the diet of the gilthead seabream in its northern range of distribution, with specimens collected from the center of the Bay of Biscay to the southern coast of England. Such data should allow testing of the hypothesis that $S$. aurata adapts its diet when colonising new areas and takes advantage of food provided by shellfish farms.

\section{Materials and methods}

\subsection{Fish and stomach content sampling}

A total of 200 wild fish were collected between January 2013 and October 2015 at seven sites in the northeast part of the species distribution: the English Channel, Brittany and middle of the Bay of Biscay (location and distribution in Fig. 1). Fish were obtained from recreational fishermen by angling or spearfishing (Concarneau site, Cc) and professional fishermen by trawling (all sites). Once collected, fish were sexed, weighed and measured (total and fork length). The following organs were dissected and weighed: gonads, liver, full digestive tract and empty digestive tract. Stomach contents were carefully collected to avoid contamination by gastrointestinal cells, filtered, rinsed twice in $96 \%$ ethanol and weighed. Hard parts contained in stomachs, such as shells, bones and opercula, and soft tissues were identified to the lowest taxonomic level using taxonomic keys, field guides and consultation with experts. Unidentified soft tissue items were isolated for genetic analysis. Prey items were counted if possible, weighed (to the nearest $0.1 \mathrm{~g}$ ) and pictures were taken with a binocular microscope.

\subsection{Group-specific primer design}

The most abundant prey groups were defined from the morphological analysis. Given these results and the expected prey groups (Table 1), group-specific primers were either designed specifically for the study or obtained from relevant literature concerning genetic prey identification from faeces or stomach contents (Table 2). The primers used were designed for a part of the cytochrome $c$ oxidase subunit I (COI) region of mitochondrial DNA and a part of the $16 \mathrm{~S}$ region of ribosomal DNA. Primers were designed on DNA sequences from species commonly found in the coastal seas of the northeastern Atlantic that were likely to be preyed on by $S$. aurata. Sequences were found on BoldSystems (Ratnasingham and Hebert 2007) for COI sequences and Genbank (Geer et al. 2010) for $16 \mathrm{~S}$ sequences. After alignments, portions around 20 bp with approximately 200 bp between forward and reverse primers were selected, according to the following rules: a percentage of $\mathrm{GC}$ around $50 \%$; melting temperatures for both primers not differing more than $5{ }^{\circ} \mathrm{C}$ and being between $40{ }^{\circ} \mathrm{C}$ and $60^{\circ} \mathrm{C}$; having no primer-dimers; and with a $\mathrm{GC}$ poor 
Table 2. Primers used in the study. Annealing temperatures (Ta) are based on the citation reference or designed for the study using gradient PCR.

\begin{tabular}{|c|c|c|c|c|c|}
\hline Gene & Target taxon & Sequence 5'-3' & Size (bp) & $\mathrm{Ta}\left({ }^{\circ} \mathrm{C}\right)$ & References \\
\hline \multirow{5}{*}{$\mathrm{COI}$} & Universal & $\begin{array}{l}\text { GGTCAACAAATCATAAAGATATTGG } \\
\text { TAAACTTCAGGGTGACCAAAAAATCA }\end{array}$ & 710 & 45 & Folmer et al. (1994) \\
\hline & Mussel & $\begin{array}{l}\text { CGGATAAAGGGGTAGGTGCT } \\
\text { GCTCAGCTCGTTCTCCTTTT }\end{array}$ & 185 & 55 & Present study \\
\hline & Oyster & $\begin{array}{l}\text { GCARTTTCCTCGAWTRAATGC } \\
\text { AAGTTGATAAAGGAGGGTA }\end{array}$ & 110 & 47 & Present study \\
\hline & Crab & $\begin{array}{l}\text { GCTATYGCYCAYGCTGGWGC } \\
\text { CGCAGTAATAAAAACAGCTC }\end{array}$ & 165 & 51 & Present study \\
\hline & Decapod & $\begin{array}{l}\text { GGTCAACAAATCATAAAGATATTGG } \\
\text { CTACTGAAGCTCCTGCRTGRGCRA }\end{array}$ & 408 & 60 & Zuccon et al. (2012) \\
\hline \multirow{4}{*}{$16 \mathrm{~S}$} & Universal & $\begin{array}{c}\text { CGCCTGTTTATCAAAAACAT } \\
\text { CCGGTCTGAACTCAGATCACGT }\end{array}$ & 590 & 55 & Palumbi (1996) \\
\hline & Crustacean & $\begin{array}{l}\text { ACTGTGCTAAGGTAGCATAA } \\
\text { CTGTTATCCCYRARGTA }\end{array}$ & 200 & 45 & Present study \\
\hline & Decapod & $\begin{array}{l}\text { ACTTTTAAGTGAAAAGGC } \\
\text { GTTATCCCTAAAGTAACTT }\end{array}$ & 300 & 45 & Present study \\
\hline & Fish & $\begin{array}{l}\text { AGACCCTATGGAGCTTTAGAC } \\
\text { CGCTGTTATCCCTATGGTAACT }\end{array}$ & 250 & 55 & Braley et al. (2010) \\
\hline
\end{tabular}

region at the 3' terminus. Gradient PCR was used on fresh tissue of a few species inside each group to maximise the specificity of PCR amplification and determine the annealing temperature. PCR was performed in a $25 \mu \mathrm{L}$ volume containing $1 X$ GoTaq G2 Green Master Mix (Promega), $0.4 \mu \mathrm{M}$ of each primer and $100 \mathrm{ng}$ of template DNA. The amplification conditions were $94{ }^{\circ} \mathrm{C}$ for $3 \mathrm{~min}, 30$ cycles of $1 \mathrm{~min}$ at $94{ }^{\circ} \mathrm{C}$, 1 min at $40{ }^{\circ} \mathrm{C}$ to $60{ }^{\circ} \mathrm{C}$ and $1 \mathrm{~min}$ at $72{ }^{\circ} \mathrm{C}$, and a final extension at $72{ }^{\circ} \mathrm{C}$ for $10 \mathrm{~min}$. The amplified DNA fragments were visualised by electrophoresis in $1 \%$ agarose gel stained with ethidium bromide and the temperature with the best PCR product was chosen as the annealing temperature (Table 2 ).

\subsection{Assay of controlled predation}

Farmed fish of three size classes were collected from the Douhet hatchery (Oleron, France): 11,8 and 4 fish of respective total length $(L)=261 \pm 6 \mathrm{~mm}, 363 \pm 18 \mathrm{~mm}$ and $445 \pm 17 \mathrm{~mm}$ and respective mass $(M)=313 \pm 28 \mathrm{~g}, 910 \pm 105 \mathrm{~g}$ and $1524 \pm 206 \mathrm{~g}$ [mean \pm S.D.]. They were used as a predator in laboratory experiments in order to evaluate the digestion duration and to determine its impact on the identification of prey by morphological and genetic methods. Fish were first acclimated to natural seawater conditions in a $630 \mathrm{~L}$ tank (opaque sides, open circulating system) for at least one month and fed with crabs, mussels and limpets. Fish were separated two at a time into another $90 \mathrm{~L}$ tank, in which experiments were held, with transparent sides and an open circulating system $(1.7 \mathrm{~L} / \mathrm{min})$. The water temperature ranged from $13{ }^{\circ} \mathrm{C}$ to $20^{\circ} \mathrm{C}$ according to natural daily variation. Three days before the experimentation, fish were fasted in order to remove traces of other prey. Fish were then fed with fresh mussels and oysters tissue and their feeding was monitored to both ensure feeding took place and for accurate determination of post-ingestion time. At specified time-intervals ( $t=2.5 \mathrm{~h}, 5 \mathrm{~h}, 12 \mathrm{~h}, 18 \mathrm{~h}$ and $24 \mathrm{~h}$ ), fish were anaesthetised with eugenol (as stipulated in the French regulation on animal research), killed, and their digestive system was dissected. Morphological identification of prey took place just after the dissection to avoid colour change of prey due to ethanol. An index was given for each prey: (1) intact and recognizable, $(0)$ some digested prey material but unidentifiable. Prey tissues were then conserved in absolute ethanol for DNA analysis. Some DNA fragments of all prey samples were amplified by PCR with universal primers of COI (Table 2) according to the protocol below and amplifications were visualised on $1 \%$ agarose gels. Specific primers of mussel and oyster (Table 2) were used in order to identify the effect of primers on DNA amplification. DNA results were expressed in the same way: (1) amplification that could lead to identification, (0) no amplification probably due to the high level of DNA degradation. Kruskal-Wallis non-parametric tests were used with R software (R ) in order to analyse the influence of time after ingestion on prey identification and to determine the primers' ability to amplify prey DNA. In case of significant influence, pairwise comparisons using post-hoc tests (Nemenyi post-hoc test, package "PMCMR") were made in order to determine which differences were significant.

\subsection{Analysis of DNA stomach contents of wild fish}

DNA of morphologically unidentifiable prey from wild fish was isolated following the cetrimonium bromide (CTAB) method without PVP (polyvinylpyrrolidone). DNA quantity and quality were assessed by spectrophotometer (NanoVue Plus, GE Healthcare). PCR reaction was performed as described for primer design using 5 to $1000 \mathrm{ng}$ of template DNA and the amplification conditions included an initial denaturation at $94{ }^{\circ} \mathrm{C}$ for $3 \mathrm{~min}, 40$ cycles of $1 \mathrm{~min}$ at $94{ }^{\circ} \mathrm{C}, 30 \mathrm{~s}$ at Ta (Table 2) and $1 \mathrm{~min}$ at $72{ }^{\circ} \mathrm{C}$, and the final step at $72{ }^{\circ} \mathrm{C}$ 
for $10 \mathrm{~min}$. PCR products were analysed by electrophoresis on a $1 \%$ agarose gel and purified using Wizard SV Gel and PCR Clean-Up System (Promega) following the manufacturer's instructions. PCR products were sequenced in the forward direction using the same primer as used for PCR amplification and according to the protocol of the BigDye Terminator Cycle Sequencing Kit v. 3. 1. (Life Technologies). Products were purified following an ethanol purification protocol and then run on an ABI Hitachi 3130 capillary sequencer at the Marine Biological Station, Concarneau, France. All sequences were aligned to sequences from databases from the Basic Local Alignment Search Tool (Altschul et al. 1990) and BOLD Identification System (Ratnasingham and Hebert 2007). Heuristic alignments are based on the similarity between the query and the database. Sequences matching with a similarity score of $100 \%$ and an E-value equal to 0 were considered as a successful match. More than five matching sequences were considered as sufficient to confirm species identification.

\subsection{Data processing and statistical analyses}

An index of vacuity was used to express the number of empty stomachs encountered as a percentage of the total stomachs examined. Only individuals with full stomachs were included in further analyses.

In order to appraise whether enough samples had been collected to describe diet precisely and for subsequent comparisons, cumulative prey curves (Ferry and Cailliet 1996) were computed with R software (package "Vegan"). The estimated number of unique prey categories and associated $95 \%$ confidence intervals were plotted against the cumulative number of guts analysed. This approach relies on the random addition of samples by simulating 100 permutations. Cumulative curves that reached a stable asymptote with the slope of the linear regression $(b)$ calculated over the last five sub-samples less than or equal to 0.05 were considered sufficient for diet identification (Brown et al. 2012).

The diet composition was analysed at two taxonomic levels. First, prey items were processed at the species level. Second, prey items were pooled into 12 major categories (classes) according to The Phylogenetic Classification of Life described in Lecointre and Le Guyader (2001): (1) Malacostraca, (2) Maxillopoda, (3) Bivalvia, (4) Polyplacophora, (5) Gastropoda, (6) Cephalopoda, (7) Polychaeta, (8) Actinopterygii, (9) Echinoidea, (10) Ophiuroidea, (11) Florideaphycea and (12) all other algae species. As the access to prey is dependent on the ease of catching the prey, prey were categorized into four life history strategies: (S) sessile and slow moving, (B) benthic, (BS) benthic swimmer and (P) pelagic.

The assessment of diet change was evaluated at different levels. First, diet composition was analysed and compared among sites. In order to test the effect of the latitudinal position on diet of $S$. aurata, sites were defined by three geographic areas: English Channel (including Bay of Bournemouth (Bo) and Bay of Torquay (Er)), Brittany (including Brest (Br), Concarneau $(\mathrm{Cc})$, Lorient (Lo) and Quiberon $(\mathrm{Qu})$ ) and Bay of Biscay (Royan (Ro)). Secondly, predator fish were classified into four size categories relating to the expected length at which the sex
Table 3. Results of Nemenyi with post-hoc test comparing genetic and morphological identification success between each time step and Kruskal-test globally. * indicates levels of significance $(p<0.05)$.

\begin{tabular}{cccc}
\hline Time after ingestion $(\mathrm{h})$ & X-squared & df & $p$-value \\
\hline 2.5 & 18.602 & 1 & $1.6111 \times 10^{-5 * * *}$ \\
5 & 13.245 & 1 & $0.0003 * *$ \\
12 & 3.619 & 1 & 0.0531 \\
18 & 9.211 & 1 & $0.0024 * *$ \\
24 & 3.778 & 1 & 0.0519 \\
\hline Globally & 40 & 1 & $2.54 \times 10^{-10} * * *$ \\
\hline
\end{tabular}

change occurs in North-Atlantic populations: $L<300 \mathrm{~mm}$ (only males), $300<L<400,400<L<500$ and $L>500 \mathrm{~mm}$ (only females). Finally, as this is a seasonally fished species, samples were only fished during the months of April, June, July, August, September and October and diet changes among months were evaluated according to these sampling periods.

The percentage of weight proportion $(\% \mathrm{~W} i)$ was calculated in order to evaluate the biomass consumed by the predator. This was determined as the mass of prey species $i$ in a predator stomach divided by the total mass of the stomach contents. Data normality was evaluated using a Shapiro-Wilk test. Since the data distribution was not normal, Kruskal-Wallis non-parametric tests were used to determine whether the relative proportions of prey consumed differed among individuals. A Friedman rank sum test with unreplicated blocked data was used to test for differences among sites, predator length categories and months of sampling. In case of significant differences, pairwise comparisons using post-hoc tests (Friedman test with post-hoc analysis, packages "coin" and "multcomp") were made in order to determine where the differences take place. Percentage of frequency of occurrence $(\% \mathrm{~F})$ was calculated as the number of fish containing the prey, divided by the number of fish with full stomach dissected. Prey were categorized as main prey $(\% \mathrm{~F}>30)$, secondary prey $(5<\% \mathrm{~F}<30)$ or occasional prey $(\% \mathrm{~F}<5)$. Both indices $(\% \mathrm{~W}$ and $\% \mathrm{~F})$ were determined for each prey classification level (species, class and position in the water column) and predators' characteristics (site, size class and month of sampling). The niche breadth was assessed using Levin's index (Krebs 1989). It is determined by $\mathrm{B}=\left(\sum_{i=1}^{n} P i^{2}\right)^{-1}$ with $\mathrm{P} i$ being the proportion of each prey species $i$ in the diet of the predator and $n$ the total number of prey species. Levins' B value is minimal when individuals consumed the same unique prey (specialised diet) and maximal when a wide range of prey is consumed (generalist diet).

\section{Results}

\subsection{Assay of controlled predation}

The effect of post-ingestion time on the ability to identify prey inside stomach contents by morphological and molecular genetic determination was evaluated. In general, DNA identification success was significantly higher than morphological identification success (Table 3 ) with significant differences between each time step, except for 12 and $24 \mathrm{~h}$ after ingestion 

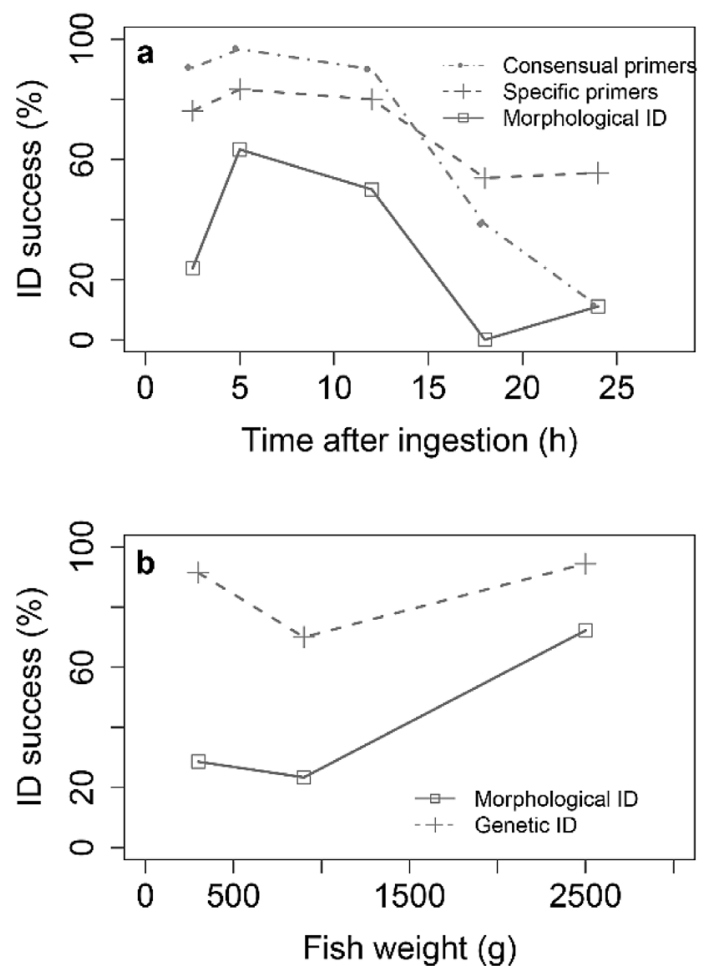

Fig. 2. Effect of digestion time (a) and fish mass (b) on morphological and genetic (with universal and specific primers) prey identification success. In (b), genetic identification success includes the use of universal and specific primers.

but with a $p$-value close to 0.05 (Nemenyi with post-hoc test, $p<0.05)$.

Using the morphological determination, identification success was particularly low at $2.5 \mathrm{~h}$ after ingestion (Fig. 2a). The percentage of morphological and DNA identification was more than $60 \%$ at $5 \mathrm{~h}$ after ingestion and then decreased as the digestion proceeded. The ability to identify prey significantly declined between $5 \mathrm{~h}$ and $24 \mathrm{~h}$ (Nemenyi post-hoc analysis, $p<0.05$ for both morphological and DNA identification).

A significant temporal effect on amplification success was observed using universal primers that became less effective with time (K-W test, $p<0.05)$. In contrast, no significant time effect was observed with specific primers showing the robustness of these primers. During the first $12 \mathrm{~h}$ of ingestion, genetic identification success was higher with universal primers (90.5\% at $2.5 \mathrm{~h}$ after ingestion) than with specific primers (76.2\% at $2.5 \mathrm{~h}$ after ingestion). After that, the pattern was reversed with identification success being higher with specific primers $(55.6 \%$ at $24 \mathrm{~h})$ than universal primers $(11.1 \%$ at $24 \mathrm{~h})$ and the difference became significant (Nemenyi post-hoc test, $p=0.05$ at $24 \mathrm{~h}$ after ingestion).

The effect of fish mass on the morphological and DNA identification of prey inside stomach contents was also determined (Fig. 2b). Globally, there was a significant effect of mass (K-W test, $p<0.05$ ). The molecular identification success was significantly lower for fish of $900 \mathrm{~g}$ than for those of 300 and $2500 \mathrm{~g}$ (Nemenyi post-hoc test, $p<0.05$ ). In contrast, morphological identification of prey was significantly higher for

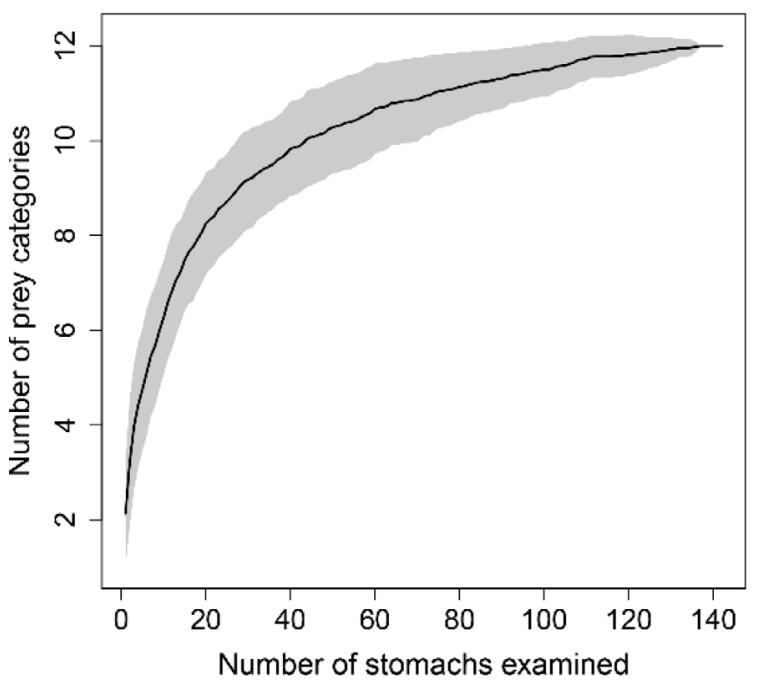

Fig. 3. Cumulative number of prey categories (solid line) and associated $95 \%$ confidence intervals from standard deviation (shaded area) for all sampled fish.

$2500 \mathrm{~g}$ fish than for other mass categories (Nemenyi post-hoc test, $p<0.05)$.

\subsection{Sampling significance}

Of the 200 wild samples, the number of full stomachs was 142 , leading to a relatively low index of vacuity $(29.0 \%)$. For mass proportion analysis, we discarded stomach contents with prey categories less than $0.1 \mathrm{~g}$, since the mass of such prey could not be measured, and analysed the remaining ones, namely 135 stomach contents. Cumulative curves were calculated to assess the significance of our sampling for diet analysis (i) globally, (ii) per site, (iii) per size class, and (iv) per month of sampling. Overall, the number of fish sampled was sufficient ( $b=0.006$, Fig. 3). At the Er, $\mathrm{Br}$ and Ro sites, the sampling was sufficient $(b<0.05)$ with 18,15 and 30 individuals, respectively. Almost enough individuals were sampled in $\mathrm{Cc}(b=0.07)$ with 52 individuals. Concerning the size class of predators, the sampling was sufficient for individuals between 300 and $400 \mathrm{~mm}$ and between 400 and $500 \mathrm{~mm}$ with 45 and 83 individuals, respectively $(b<0.05)$. Concerning the sample months, only October showed a sufficient number of samples collected $(b<0.05$ with $\mathrm{N}=36)$.

\subsection{Diet investigation at the taxonomic level}

At the class level (Table 4), Bivalvia, Malacostraca and Gastropoda dominated the diet of S. aurata $(\% \mathrm{~F}>30$ and $\% \mathrm{~W}>5$ ) with a large prevalence for Bivalvia. In terms of occurrence, Maxillopoda, Polychaeta, Florideaphycea and algae appear to be secondary categories of prey with $\% \mathrm{~F}$ between 5 and 30 . Other prey were occasional ones $(\% \mathrm{~F}<5)$. Considering weight proportion, Cephalopoda, Polychaeta, Actinopterygii, Ophiuridea and algae appeared to be secondary prey (\%W between 0.5 and 9) and other categories occasional prey. At the species level (Table 5), 33 species were found with 
Table 4. Percentage of frequency of occurrence $(\% \mathrm{~F})$ and percentage of weight proportion $(\% \mathrm{~W})$ for each class of prey.

\begin{tabular}{ccc}
\hline Class & $\% \mathrm{~F}$ & $\% \mathrm{~W}$ \\
\hline Malacostraca & 47.9 & 20.2 \\
Maxillopoda & 5.6 & 0.5 \\
Bivalvia & 91.6 & 64.2 \\
Polyplacophora & 4.2 & 0.3 \\
Gastropoda & 31.0 & 9.2 \\
Cephalopoda & 0.7 & 0.7 \\
Polychaeta & 14.1 & 1.5 \\
Actinopterygii & 2.8 & 1.3 \\
Echinoidea & 1.4 & 0.1 \\
Ophiuroidea & 1.4 & 0.7 \\
Florideaphycea & 9.9 & 0.4 \\
Other algae & 8.5 & 0.8 \\
\hline
\end{tabular}

Mytilus sp. $(\% \mathrm{~F}=51.4$ and $\% \mathrm{~W}=40.2)$ and Chlamys sp. $(\% \mathrm{~F}=31.0$ and $\% \mathrm{~W}=18.5)$ as the preferred prey.

Frequency of occurrence and weight proportion of prey were significantly different between prey categories $(\mathrm{K}-\mathrm{W}$ test, $p<0.05$ ) with a high prevalence of bivalves, malacostraceans and gastropods. Low differences were observed within each site, showing that most individuals ate the same categories of prey (see Fig. 1 for $\% \mathrm{~F}$ at the species level and Figure 4A for $\% \mathrm{~W}$ at the class level). With samples grouped according to latitudinal position (Fig. 4B), a significant difference between sites from the coast of Brittany and sites from the English Channel and the Bay of Biscay was observed (Friedman test with post-hoc analysis, $p<0.05$ ). The diet of individuals from the English Channel was mainly composed of Chlamys sp., shrimps, gastropods and polychaetes. Brittany samples principally contained Mytilus sp., bivalves, gastropods and crabs, whereas stomach contents of individuals from the Bay of Biscay were almost exclusively composed of Mytilus sp.

Concerning differences in diet composition relative to fish length (Fig. 4C), there was a significant difference between fish less than $300 \mathrm{~mm}$ or between 300 and $400 \mathrm{~mm}$ and fish more than $500 \mathrm{~mm}$ (Friedman test with post-hoc analysis, $p<0.05$ ). This difference was due to increasing prey diversity with fish size: the Levins' B value changes from 8.64 for individuals less than $300 \mathrm{~mm}$ to 10.31 for individuals more than $500 \mathrm{~mm}$.

Dietary composition did not vary significantly among sampling months in terms of frequency of occurrence and weight proportion. However, no sampling was possible during the migration period, from November to March. Comparison among seasons was therefore impossible. However, higher Levins' B values were observed during the warmest months, i.e. September $(\mathrm{B}=9.67)$, July $(\mathrm{B}=9.48)$, June $(\mathrm{B}=8.22)$ and August $(\mathrm{B}=7.98)$ compared to October $(\mathrm{B}=5.74)$ and April $(\mathrm{B}=1.62)$.

\subsection{Diet analysis relative to the prey's position inside the water column}

In terms of weight proportion, sessile organisms $(\% \mathrm{~W}=$ 75.4) were much more abundant than pelagic $(\% \mathrm{~W}=2.0)$ and benthic $(\% \mathrm{~W}=14.4)$ organisms (Friedman test with posthoc analysis, $p<0.05$, Table 5), in relation with the high proportion of bivalve species (Mytilus sp. and Chlamys sp.) in-
A
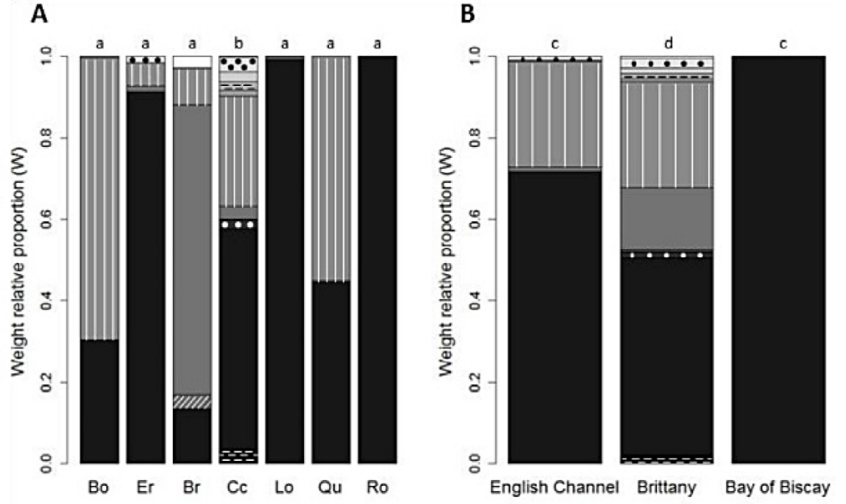

C
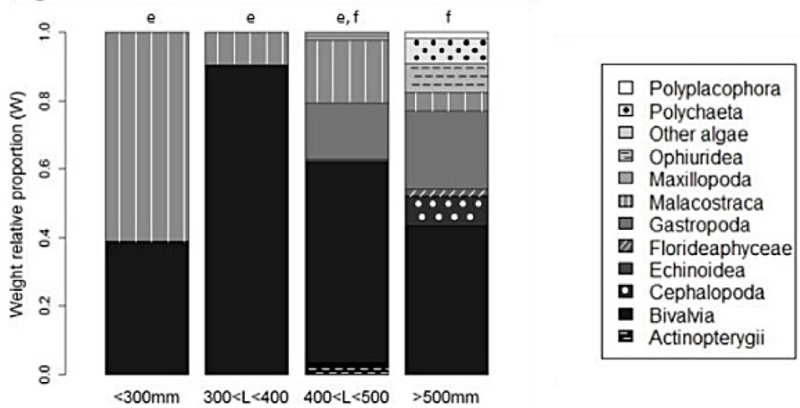

Fig. 4. Diet composition of the gilthead seabream expressed in weight relative proportion (W) by sites (A), latitudinal position (B) and size categories of predator $(\mathrm{C})$. On each graph, different lowercase letters above bars indicate significant differences according to the post-hoc analysis for the Friedman test $(p<0.05)$. N.b.: site abbreviations: see legend Figure 1.

side stomach contents. The same pattern was observed with the frequency of occurrence: sessile organisms were present at $96.5 \%$, benthic species at $47.2 \%$, benthic swimmer at $18.3 \%$ and pelagic fish at $3.5 \%$. There was no significant influence of site, latitudinal position, fish length or sampling month. All fish individuals targeted mostly bivalves.

\section{Discussion}

This study provides the first diet analysis of northern populations of $S$. aurata, and improves understanding of the feeding strategy of species in the context of northward expansion probably due to climate change. This work also demonstrated that DNA-based techniques can be used for prey identification when morphological determination cannot.

With a growing need for diet determination techniques in ecological studies, more advanced approaches than traditional diet analysis have emerged, including fatty-acid analysis, stable-isotope analysis and DNA-based techniques (CarreonMartinez and Heath 2010; Escalas et al. 2015; Espinoza et al. 2015). The use of fatty-acid and stable isotopes techniques limits tissue damage but requires a complete knowledge of prey isotopic signatures, which can be difficult to acquire. Furthermore, these techniques can be used to describe food webs by giving a trophic position to organisms, but they do not allow specific identification of prey.

PCR-based techniques are increasingly used for diet determination (Valentini et al. 2009; Carreon-Martinez et al. 2011). 
Table 5. Prey-specific indices of percentage of frequency of occurrence $(\% \mathrm{~F})$ and percentage of weight proportion (\%W) for each prey item identified by morphological and genetic analysis in the diet of Sparus aurata. Species were grouped into 12 classes for analysis (in bold characters). Several prey items were not identified to the species level and were included inside unidentified groups. Life history strategy groups: (S) sessile and slow moving, (B) benthic, (BS) benthic swimmer and (P) pelagic organisms.

\begin{tabular}{|c|c|c|c|c|c|c|}
\hline Phylum & Class & Order & Species & Location inside the water column & $\% \mathrm{~F}$ & $\% \mathrm{~W}$ \\
\hline \multirow{12}{*}{ Arthropoda } & \multirow{10}{*}{ Malacostraca } & \multirow{10}{*}{ Decapoda } & Crangon crangon & $\overline{B S}$ & 1.4 & 0.7 \\
\hline & & & Palaemon serratus & BS & 2.1 & 1.4 \\
\hline & & & Unidentified shrimps & BS & 12.7 & 5.0 \\
\hline & & & Necora puber & B & 1.4 & 0.0 \\
\hline & & & Xantho pilipes & B & 0.7 & 0.1 \\
\hline & & & Cancer pagurus & B & 0.7 & 0.0 \\
\hline & & & Carcinus maenas & B & 7.0 & 3.4 \\
\hline & & & Liocarcinus navigator & B & 0.7 & 0.0 \\
\hline & & & Inachus dorsettensis & B & 0.7 & 0.7 \\
\hline & & & Unidentified crabs & B & 26.1 & 8.8 \\
\hline & \multirow[t]{2}{*}{ Maxillopoda } & Sessilia & $\begin{array}{l}\text { Unidentified } \\
\text { barnacles }\end{array}$ & S & 4.9 & 0.5 \\
\hline & & Calanoida & Calanus sp. & $\overline{\mathrm{BS}}$ & 0.7 & 0.0 \\
\hline \multirow{11}{*}{ Mollusca } & \multirow{5}{*}{ Bivalvia } & Mytiloida & Mytilus sp. & $\mathrm{S}$ & 51.4 & 40.2 \\
\hline & & \multirow[b]{2}{*}{ Ostreoida } & Ostrea edulis & $\mathrm{S}$ & 0.7 & 0.0 \\
\hline & & & Crassostrea gigas & S & 3.5 & 0.0 \\
\hline & & Pectinoida & Chlamys sp. & $\mathrm{S}$ & 31.0 & 18.5 \\
\hline & & & Unidentified bivalves & $\mathrm{S}$ & 27.5 & 5.5 \\
\hline & Polyplacophora & & Unidentified chitons & $\mathrm{S}$ & 4.2 & 0.3 \\
\hline & \multirow{3}{*}{ Gastropoda } & Archaeogastropoda & Unidentified top snails & $\mathrm{S}$ & 0.7 & 0.0 \\
\hline & & \multirow{2}{*}{ Mesogastropoda } & Littorina littorea & $\bar{S}$ & 0.7 & $\overline{0.0}$ \\
\hline & & & Crepidula fornicata & $S$ & 1.4 & 0.0 \\
\hline & & & $\begin{array}{l}\text { Unidentified } \\
\text { gastropods }\end{array}$ & $S$ & 30.3 & 9.2 \\
\hline & Cephalopoda & Teuthoida & Loligo sp. & $\mathrm{P}$ & 0.7 & 0.7 \\
\hline \multirow{3}{*}{ Annelida } & \multirow{3}{*}{ Polychaeta } & Oweniidae & Owenia fusiformis & B & 0.7 & 0.0 \\
\hline & & Phyllodocida & Aphrodita aculeata & $\mathrm{BS}$ & 1.4 & 1.0 \\
\hline & & & $\begin{array}{l}\text { Unidentified } \\
\text { polychaetes }\end{array}$ & B & 12.0 & 0.6 \\
\hline \multirow{3}{*}{ Chordata } & \multirow{3}{*}{ Actinopterygii } & Perciformes & Callionymus sp. & $\mathrm{P}$ & 0.7 & 0.0 \\
\hline & & Perciformes & Trachurus trachurus & $\mathrm{P}$ & 1.4 & 1.3 \\
\hline & & Gadiformes & Pollachius pollachius & $\mathrm{P}$ & 0.7 & 0.0 \\
\hline \multirow{2}{*}{ Echinodermata } & \multirow{2}{*}{$\begin{array}{l}\text { Echinoidea } \\
\text { Ophiuroidea }\end{array}$} & & $\begin{array}{l}\text { Unidentified } \\
\text { echinoides }\end{array}$ & B & 1.4 & 0.1 \\
\hline & & Ophiurida & $\begin{array}{l}\text { Unidentified } \\
\text { ophiuroids }\end{array}$ & B & 1.4 & 0.7 \\
\hline Rhodophyta & Florideaphyceae & Corallinales & $\begin{array}{c}\text { Unidentified corraline } \\
\text { algae }\end{array}$ & S & 9.9 & 0.4 \\
\hline Algae & Algaea & & Other algae & $\mathrm{S}$ & 8.5 & 0.8 \\
\hline
\end{tabular}

DNA-based techniques have been largely carried out to identifying prey species inside stomach contents or gut samples (Symondson 2002) and the supply of DNA sequence databases allows and supports the use of molecular genetic techniques to characterise as specifically as possible the diet of marine organisms. In this study, the use of two complementary identification techniques allowed reliable prey determination and analysis of diet composition. The laboratory experiments showed increased identification success associated with the use of genetic tools. This pattern is consistent with that reported by Carreon et al. (2011) based on three fish species.

In most studies, only universal primers are used for genetic determination of prey. The design of specific primers for a given study is quite uncommon due to its high cost and the need for knowledge of target prey sequences. The efficiency of group-specific primers in amplifying degraded DNA extracted from gut samples is however much higher than that of universal primers (Jarman et al. 2004; Deagle et al. 2005; Taguchi et al. 2014). With universal primers, the risk of mislabeling is higher because of possible amplification of DNA from other prey which are in contact inside the digestive tract, and also by the possibility of amplifying predator DNA. Moreover, DNA degradation during the digestion process decreases the efficiency of primers and the possibility of amplifying long fragments. In our study, specific primers were more efficient than universal primers on stomach samples several hours after ingestion.

Although stomach content analysis appears to be the best way to specifically determine the diet of marine fishes, indices currently used to characterise diet composition remain critical 
(Brown et al. 2012). In most studies, indices used for diet characterisation involve assessment of the number and mass of each prey inside the stomach content. Typically used indices are the percent number of prey $\% \mathrm{~N}_{i}$ (number of prey species $i$ divided by the total number of prey species found in all stomachs), the percent weight of prey $\% \mathrm{~W}_{i}$ (mass of the prey species $i$ divided by the total mass of all stomach contents) and the frequency of occurrence $\% \mathrm{~F}_{i}$ (number of predators that preyed upon species $i$ divided by the total number of predators with full stomachs). Depending on the species studied, a count of prey individuals can sometimes be made (Espinoza et al. 2015) but for predator species which can crush their prey between their teeth, it is, in most cases, impossible to identify whether the pieces of tissue or skeleton come from one or more individuals. In this case, the measurement of the standardised Index of Relative Importance (IRI), calculated as: $\% \mathrm{IRI}=\left(\% \mathrm{~N}_{i}+\% \mathrm{~W}_{i}\right) \% \mathrm{~F}_{i}$, cannot be done. The more consistent index, the Prey-Specific Index of Relative Importance (\%PSIRI), cannot be used either (Brown et al. 2012). This work is therefore based only on the use of $\mathrm{W}_{i}$ as analysis of ingested biomass and $\mathrm{F}_{i}$ in terms of prey consumption opportunity.

The diet of the gilthead seabream sites studied can provide classification of preferred prey: (1) Main prey $(\% \mathrm{~F}>30)$ with Bivalvia, Malacostraca and Gastropoda; (2) Secondary prey $(5<\% \mathrm{~F}<30)$ with Maxillopoda, Polychaeta, Florideophyceae and other algae; and (3) Occasional prey $(\% \mathrm{~F}<$ 5) with Polyplacophora, Cephalopoda, Actinopterygii, Echinoidea and Ophiuroidea. However, given the nature of these prey, Algae and Florideophyceae may be additional prey, as they are probably not eaten by choice. In terms of ingested biomass, main prey are the same; Cephalopoda, Actinopterygii, Ophiuridea, Polychaeta and other algae are secondary prey, whereas Maxillopoda, Florideophyceae, Polyplacophora and Echinoidea appear to be occasional prey. The feeding pattern observed in this study shows slightly different preferences when compared to Mediterranean populations. Bivalves are among main prey in each diet study of $S$. aurata, and malacostracans and gastropods are also found in the diet of Mediterranean gilthead seabream (Table 1).

A higher diversity in prey species is observed inside stomach contents of fish from Cc, with a Levins' B value of 9.12 compared to other sites, where foraging on almost only bivalves and malacostracans occurs. The $\mathrm{Cc}$ fish were sampled by trawling and angling, while all other individuals were from trawling only. The potential influence of the fishing method was tested within the Cc samples and no significant influence was observed (data not shown), meaning that the higher diversity of prey found in the $\mathrm{Cc}$ site cannot be explained by the fishing method used. This difference could be justified by a larger diversity of available species at this site. This hypothesis cannot currently be tested because of the lack of data on diversity and species richness, but it seems unlikely that the potential prey diversity is higher in $\mathrm{Cc}$ than in nearby sites (i.e. $\mathrm{Br}$ ). However, the gilthead seabream might not have found enough primary prey and have turned to other available food sources. Cumulative curves indicated that the sample size was not sufficient at Bo, Lo and $\mathrm{Qu}$ to allow comparison among sampling sites. However, grouping samples by latitudinal position allowed us to assert that no Mytilus sp. were found in stomachs of individuals from the English Channel, which contain Chlamys sp., shrimps, gastropods and polychaetes. The large variety of prey attributed to samples from the South Brittany coast was in fact largely due to individuals from Cc (Mytilus sp., bivalves, gastropods and crabs), whereas samples from the center of the Bay of Biscay fed almost exclusively on Mytilus sp. The absence of mussels inside stomach contents of samples from the English Channel can be explained by the absence of mussels close to the areas in which the individuals were fished, related to habitats that are different to those in Brittany. Diet may depend on opportunity since the gilthead seabream is able to eat diverse types of prey (Pita et al. 2002; Tancioni et al. 2003; Chaoui et al. 2005; Hadj Taied et al. 2013) and has a relatively high migration ability (Sánchez-Lamadrid 2002; Mercier et al. 2012). The prey encountered may be determined by the habitats used. This result reflects the opportunistic behaviour of $S$. aurata in its distribution range.

The results of our study also show that the diversity of prey increases with fish length. A significant difference was observed between fish less than $400 \mathrm{~mm}$ and more than $500 \mathrm{~mm}$. Cumulative curves indicated that the sample size was not sufficient for fish length less than $300 \mathrm{~mm}$ and more than $500 \mathrm{~mm}$. A greater sampling effort is therefore needed to confirm this analysis but it is not surprising that larger individuals can catch a more diverse range of prey due to their teeth morphology and jaw power being adapted to shell grinding. This is consistent with the work of Hadj Taieb et al. (2013) who showed that juveniles tend to consume a less diverse range of prey species than larger specimens. Finally, no difference was observed among the sampling months, perhaps due to the non-sufficient sampling for most sample months, according to the cumulative curves. The most frequent prey (bivalves and gastropods) are sessile species which do not migrate according to the season. However, the warmest months correspond to the recruitment period for most invertebrate species. The higher Levins' B values observed during this time of the year could be explained by the increased abundance of prey species. Diet seasonal variations were observed for populations of the Mediterranean Sea with a lower diversity of prey during winter due to food availability (Wassef and Eisawy 1985). During summer, the predator could allocate more energy to foraging.

\section{Conclusion}

Knowing the food strategy of a species in expansion in a new environment is useful to predict the potential impact on the native fauna and shellfish farms. Over the past ten years, a significant increase of the size of wild gilthead seabream populations has been documented along the coasts of Brittany and the northern coast of France (FAO 2015). Prey availability in an ecosystem can be a limiting factor for the establishment of a new fish species but $S$. aurata seems to meet its food needs. This study found a strong preference of $S$. aurata for sessile organisms $(\% \mathrm{~F}=96.5, \% \mathrm{~W}=75.4)$, which demonstrates the ability of $S$. aurata to catch, crunch and digest its prey. With a percentage of frequency of occurrence of $51.4 \%$ and a percentage of relative weight proportion of $40.2 \%$, mussels appear to be the main prey species of the gilthead seabream 
in the northern range of its distribution. Given the damage identified as being due to predation by the gilthead seabream in shellfish farms in the Mediterranean Sea and along the coast of Brittany, it would be well advised to consider this future impact at the sites on the edge of the present species distribution (both sides of the English Channel).

Acknowledgements. This research was funded by the Brittany region and supported by the Regional Committee of Aquaculture of South Brittany and the Pole Mer Bretagne. The authors thank Ronan Le Faou, Thomas Gestin, Elena Luchetti and Pascal Mottier for sampling. Thanks are due to the "Ferme Marine du Douhet" for the supply of farmed fish. Many thanks to Samuel Iglesias, Eric Feunteun, Julien Ringelstein, Sébastien Baratte, Gwen Godefroy and all taxonomist experts for their review and precious help.

\section{References}

Altschul S.F., Gish W., Miller W., Myers E.W., Lipman D.J., 1990, Basic Local Alignment Search Tool. J. Mol. Biol. 215, 403-410.

Anonymous, 2014, Des dorades dévorent la production en rade de Brest. Le Marin, 10 Octobre 2014.

Avise J.C., Arnold J., Ball R.M., Bermingham E., Lamb T., Neigel J.E., Reeb C.A., Saunders N.C., 1987, Intraspecific phylogeography: The Mitochondrial DNA Bridge Between Population Genetics and Systematics. Annu. Rev. Ecol. Syst. 18, 489-522.

Beaugrand G., Kirby R.R., 2010, Climate, plankton and cod. Glob. Change Biol. 16, 1268-1280.

Braley M., Goldsworthy S.D., Page B., Steer M., Austin J.J., 2010, Assessing morphological and DNA-based diet analysis techniques in a generalist predator, the arrow squid Nototodarus gouldi. Mol. Ecol. Resour. 10, 466-474.

Brown S.C., Bizzarro J.J., Cailliet G.M., Ebert, D.A., 2012, Breaking with tradition: redefining measures for diet description with a case study of the Aleutian skate Bathyraja aleutica (Gilbert 1896). Environ. Biol. Fishes 95, 3-20.

Carlton J.T., 1993, Neoextinctions of Marine Invertebrates. Am. Zool. 33, 499-509.

Carreon-Martinez L., Heath D.D., 2010, Revolution in food web analysis and trophic ecology: diet analysis by DNA and stable isotope analysis. Mol. Ecol. 19, 25-27.

Carreon-Martinez L., Johnson T.B., Ludsin S.A., Heath D.D., 2011, Utilization of stomach content DNA to determine diet diversity in piscivorous fishes. J. Fish Biol. 78, 1170-1182.

Chaoui L., Derbal F., Kara M.H., Quignard J.-P., 2005, Alimentation et condition de la dorade Sparus aurata (Teleostei: Sparidae) dans la lagune du Mellah (Algérie Nord-Est). Cah. Biol. Mar. 46, 221-225.

Corse E., Costedoat C., Chappaz R., Pech N., Martin J.-F., Gilles A., 2010, A PCR-based method for diet analysis in freshwater organisms using $18 \mathrm{~S}$ rDNA barcoding on faeces. Mol. Ecol. Resour. 10, 96-108.

Coscia I., Vogiatzi E., Kotoulas G., Tsigenopoulos C.S., Mariani S., 2011, Exploring neutral and adaptive processes in expanding populations of gilthead sea bream, Sparus aurata L., in the North-East Atlantic. Heredity 108, 537-546.

Craig G., Paynter D., Coscia I., Mariani S., 2008, Settlement of gilthead sea bream Sparus aurata L. in a southern Irish Sea coastal habitat. J. Fish Biol. 72, 287-291.

Deagle B.E., Jarman S.N., Pemberton D., Gales N.J., 2005, Genetic Screening for Prey in the Gut Contents from a Giant Squid (Architeuthis sp.). J. Hered. 96, 417-423.
Dulvy N.K., Rogers S.I., Jennings S., Stelzenmller V., Dye S.R., Skjoldal H.R., 2008, Climate change and deepening of the North Sea fish assemblage: a biotic indicator of warming seas. J. Appl. Ecol. 45, 1029-1039.

Edwards M., Richardson A.J., 2004, Impact of climate change on marine pelagic phenology and trophic mismatch. Nature 430, 881-884.

Escalas A., Ferraton F., Paillon C., Vidy G., Carcaillet F., SalenPicard C., Le Loc'h F., Richard P., Darnaude A.M., 2015, Spatial variations in dietary organic matter sources modulate the size and condition of fish juveniles in temperate lagoon nursery sites. Estuar. Coast. Shelf Sci. 152, 78-90.

Espinoza M., Munroe S.E.M., Clarke T.M., Fisk A.T., Wehrtmann I.S., 2015, Feeding ecology of common demersal elasmobranch species in the Pacific coast of Costa Rica inferred from stable isotope and stomach content analyses. J. Exp. Mar. Biol. Ecol. $470,12-25$.

Fahy E., Green P., Quigley D.T.G., 2005, Juvenile Sparus aurata L. on the south coast of Ireland. J. Fish Biol. 66, 283-289.

FAO Statistics, 2015, in: FAO Fisheries and Aquaculture Department . Accessed September 2015. http://www.fao.org/fishery/statistics/ en

Ferry L.A., Cailliet G.M., 1996, Sample size and data analysis: are we characterizing and comparing diet properly? In: MacKinlay D. and Shearer K. (Eds.), Feed. Ecol. Nutr. Fish, International Congress of the Biology of Fishes. American Fisheries Society, Bethesda, MD, pp. 71-80.

Folmer O., Black M., Hoeh W., Lutz R., Vrijenhoek R., 1994, DNA primers for amplification of mitochondrial cytochrome $c$ oxidase subunit I from diverse metazoan invertebrates. Mol. Mar. Biol. Biotechnol. 3, 294-299.

Geer L.Y., Marchler-Bauer A., Geer R.C., Han L., He J., He S., Liu C., Shi W., Bryant S.H., 2010, The NCBI BioSystems database. Nucleic Acids Res. 38, 492-496.

Glamuzina B., Pešić A., Joksimović A., Glamuzina L., Matić-Skoko S., Conides A., Klaoudatos D., Zacharaki P., 2014, Observations on the increase of wild gilthead seabream, Sparus aurata abundance, in the eastern Adriatic Sea: problems and opportunities. Int. Aquat. Res. 6, 127-134.

Gorokhova E., 2006, Molecular identification of the invasive cladoceran Cercopagis pengoi (Cladocera: Onychopoda) in stomachs of predators. Limnol. Oceanogr. Methods 4, 1-6.

Hadj Taied A., Sley A., Ghorbel M., Jarboui O., 2013, Feeding habits of Sparus aurata (Sparidae) from the Gulf of Gabes (central Mediterranean). Cah. Biol. Mar. 54, 263-270.

Jarman S.N., Deagle B.E., Gales N.J., 2004, Group-specific polymerase chain reaction for DNA-based analysis of species diversity and identity in dietary samples. Mol. Ecol. 13, 1313-1322.

Krebs C.J., 1989, Ecological Methodology. Harper Collins: New York.

Lecointre G., Le Guyader G., 2001, Classification phylogénétique du vivant. Belin: Paris.

Lenoir S., Beaugrand G., Lecuyer Ér., 2011, Modelled spatial distribution of marine fish and projected modifications in the North Atlantic Ocean. Glob. Change Biol. 17, 115-129.

Mariani S., 2006, Life-history- and ecosystem-driven variation in composition and residence pattern of seabream species (Perciformes: Sparidae) in two Mediterranean coastal lagoons. Recent Dev. Estuar. Ecol. Manag. 53, 121-127.

Mercier L., Mouillot D., Bruguier O., Vigliola L., Darnaude A.M., 2012, Multi-element otolith fingerprints unravel sea-lagoon lifetime migrations of gilthead sea bream Sparus aurata. Mar. Ecol. Prog. Ser. 444, 175-194. 
Meusnier I., Singer G.A.C., Landry J.-F., Hickey D.A., Hebert P.D.N., Hajibabaei, M., 2008, A universal DNA mini-barcode for biodiversity analysis. BMC Genomics 9, 214.

Montero-Serra I., Edwards M., Genner M.J., 2015, Warming shelf seas drive the subtropicalization of European pelagic fish communities. Glob. Change Biol. 21, 144-153.

Occhipinti-Ambrogi A., 2007, Global change and marine communities: Alien species and climate change. Mar. Pollut. Bull. 55, 342-352.

Palumbi S.R., 1996, Nucleic acid II: the polymerase chain reaction. In: Hillis D.M., Moritz C., Mable. B.K. (Eds.), Mol. Syst., 205-247.

Paquin M.M., Buckley T.W., Hibpshman R.E., Canino M.F., 2014, DNA-based identification methods of prey fish from stomach contents of 12 species of eastern North Pacific groundfish. DeepSea Res. I 85, 110-117.

Parmesan C., Yohe G., 2003, A globally coherent fingerprint of climate change impacts across natural systems. Nature 421, 37-42.

Pita C., Gamito S., Erzini K., 2002, Feeding habits of the gilthead seabream (Sparus aurata) from the Ria Formosa (southern Portugal) as compared to the black seabream (Spondyliosoma cantharus) and the annular seabream (Diplodus annularis). J. Appl. Ichthyol. 18, 81-86.

Quigley D.T.G., 2015, GILTHEAD SEA-BREAM (Sparus aurata L.) in Irish Waters. Sherkin Comment 2015, 59.

R, 2015, R Core Team: A language and environment for statistical computing. Vienna, Austria. Available at: https://www.R-project. org/

Ratnasingham S., Hebert P.D.N., 2007, BOLD: The Barcode of Life Data System (http://www.barcodinglife.org). Mol. Ecol. Notes 7, 355-364.
Rindorf A., Lewy P., 2006, Warm, windy winters drive cod north and homing of spawners keeps them there. J. Appl. Ecol. 43, 445-453.

Sánchez-Lamadrid A., 2002, Stock enhancement of gilthead sea bream (Sparus aurata, L.): assessment of season, fish size and place of release in SW Spanish coast. Aquaculture 210, 187-202.

Šegvić-Bubić T., Grubišić L., Karaman N., Tičina V., Jelavić K.M., Katavić I., 2011, Damages on mussel farms potentially caused by fish predation - Self-service on the ropes? Aquaculture 319, 497-504.

Symondson W.O.C., 2002, Molecular identification of prey in predator diets. Mol. Ecol. 11, 627-641.

Taguchi T., Miura Y., Krueger D., Sugiura S., 2014, Utilizing stomach content and faecal DNA analysis techniques to assess the feeding behaviour of largemouth bass Micropterus salmoides and bluegill Lepomis macrochirus. J. Fish Biol. 84, 1271-1288.

Tancioni L., Mariani S., Maccaroni A., Mariani A., Massa F., Scardi M., Cataudella S., 2003, Locality-specific variation in the feeding of Sparus aurata L.: evidence from two Mediterranean lagoon systems. Estuar. Coast. Shelf Sci. 57, 469-474.

Valentini A., Pompanon F., Taberlet P., 2009, DNA barcoding for ecologists. Trends Ecol. Evol. 24, 110-117.

Wassef E., Eisawy A., 1985, Food and feeding habits of wild and reared gilthead bream Sparus aurata L. Cybium 9, 233-242.

Zuccon D., Brisset J., Corbari L., Puillandre N., Utge J., Samadi S., 2012, An optimised protocol for barcoding museum collections of decapod crustaceans: a case-study for a 10-40-years-old collection. Invertebr. Syst. 26, 592. 